\title{
MAJdA MeršE
}

\section{ENOSTAVČNE POVEDI V KATEKIZMU IN ABECEDNIKU (1550) PrimožA TRUbARJA}

Coвiss: 1.01

HTTPS://DOI.ORG/10.3986/JZ.27.1.02

Prispevek ima namen predstaviti (oblikovno in funkcijsko) tipologijo in $\mathrm{z}$ njo problematiko enostavčnih povedi, ki se pojavljajo $\mathrm{v}$ prvih dveh knjigah $\mathrm{v}$ slovenskem jeziku: v Katekizmu in Abecedniku Primoža Trubarja iz leta 1550. Prikaz tematsko razširja in hkrati dopolnjuje poznavanje skladenjske ravnine slovenskega knjižnega jezika 16. stoletja, kakršno so poleg Bohoričeve slovnice oblikovale dosedanje raziskave skladnje v samostojnejših Trubarjevih in Dalmatinovih besedilih, večinoma v prvi vrsti posvečene uporabljenim stilnim in retoričnim figuram.

Ključne besede: skladnja, enostavčna poved, Primož Trubar, katekizem, abecednik

\section{Simple Sentences in Primož Trubar's Catechismus and Abecedarium (1550)}

This article presents a (morphological and functional) typology and its related issues of simple sentences in the first two books in Slovenian, Catechismus and Abecedarium (1550) by Primož Trubar. This treatment not only thematically expands but also complements knowledge of the syntactic character of the sixteenth-century standard Slovenian contained in Bohorič's grammar as well as in the syntactic studies of certain of Trubar's and Dalmatin's texts, mainly dedicated to their stylistic and rhetorical devices.

Keywords: syntax, simple sentence, Primož Trubar, catechism, reader

0 Dosedanje raziskave skladenjske ravnine slovenskega knjižnega jezika 16. stoletja, 1 ki so časovno večinoma sledile drugovrstnim, kar se odraža tudi v njihovem številu in problemski širini, 2 so zlasti v samostojnejših Trubarjevih besedilih ter v Gmajn predguvori Dalmatinove Biblije analitično zaobsegle predvsem zložene stavke (Novak 1983/84). ${ }^{3}$ V povezavi s posebnim tipom besedila 4 ali ob drugač-

1 Problemski pregled skladenjskih obravnav jezika slovenskih protestantskih piscev 16. stoletja je ob petstoti obletnici Trubarjevega rojstva pripravil K. Ahačič (2008-2009).

2 Prim. Pogorelec 2011 (1972): 243, ki navaja, da je raziskovanje sloga (in z njim skladnje) Trubarjevega jezika sledilo predhodnim raziskavam črkopisa, govorne osnove, glasoslovja in oblikoslovja. Na dejstvo, da je skladnja manj obdelano področje slovenskega knjižnega jezika 16. stoletja, opozarja tudi J. Müller (2008-2009: 181).

3 Novak npr. ugotavlja tipologijo priredij in podredij, značilnih za Gmajn predguvor Dalmatinove Biblije, hkrati pa izpostavlja tudi nekaj za tip besedila in za Dalmatina značilnih ubesedovalnih postopkov (npr. pogosto sklicevanje na svetopisemska besedila, ponavljanje itd.).

4 Skladenjske analize so se zdela vredna (in je bila tudi deležna) zlasti izvirno oblikovana besedila, za kakršni veljata tudi Trubarjev Katekizem in Abecednik (1550) (prim. npr. Pogorelec 1972; Sajovic 1986; Orel 2019), še izraziteje pa njegovi evangelijski povzetki (v TE 1555 in TT 1581-82), razlage v TR 1558 (o obojem Orožen 2008-2009), predgovori k novozaveznim 
nih vsebinskih in problemskih poudarkih se vzporedno omenjajo tudi enostavčne povedi. V nekaterih razpravah so tudi zloženi stavki predmet raziskave samo posredno, saj so v ospredju npr. podredni vezniki (Keber 1986; Neweklovsky 1989). V drugih obravnavah, namenjenih prikazu retoričnega oblikovanja in slogovnih značilnosti besedil slovenskih protestantskih piscev 16. stoletja, zlasti Trubarjevih5 (prim. Pogorelec 1972; Sajovic 1986; Seitz 1995) in Dalmatinovih (Pogorelec 1984; 1986), 6 so bili npr. tudi zloženi stavki upoštevani kot značilnost besedilnih enot oz. besedil, pripadajočih različnim besedilnim zvrstem. Tudi razvojni pregled rabe prostega stavka v knjižnem jeziku 16. stoletja (Pogorelec 1968) je bil problemsko osredinjen zgolj na vlogo dativa v stavku.

Večina dosedanjih razprav o skladnji v slovenskem knjižnem jeziku 16. stoletja izhaja iz prepričanja, da je šolanje Trubarju (in drugim protestantskim piscem) zagotovilo zadostno slovnično znanje in poznavanje skladnje za samostojno oblikovanje besedil,7 kasnejša pridigarska in prevajalska dejavnost pa je prispevala $\mathrm{k}$ praktični izpopolnitvi te sposobnosti.8 Kot pridigar je upošteval in s tem ohranjal retorično izročilo predprotestantske dobe (Pogorelec 2011 (1984): 232).9

0.1 Obe Trubarjevi deli - Katekizem in Abecednik - veljata za samostojnejši, prevodno le deloma odvisni besedili,10 kar je poleg tega, da gre za prvi knjigi v slovenskem jeziku, vplivalo tudi na njun izbor (zlasti delov Katekizma) za skladenjske

- prevodom (zlasti Tiga noviga testamenta ena dolga predguvor v TT 1557; Pogorelec 1972; Seitz 1995) ter TC 1575 (Pogorelec 1972), izmed Dalmatinovih pa predvsem Gmajn predguvor $\mathrm{k}$ Bibliji (Novak 1983/84; Pogorelec 1984; 1986).

$5 \quad$ Prim. Seitz 1995, ki obravnava dvojično vezniško priredje oz. dvojno formulo v izbranih besedilih Primoža Trubarja, Martina Luthra in njunih sodobnikov. Prim. tudi Orel 2019, ki predstavlja s primerjavo enakih prevodnih besedil slovenskih in hrvaških reformatorjev (Trubar 1550 in Konzul 1564 ter Krelj 1566 in Vlačić 1566) ugotovljive jezikovne razlike, izpričane na skladenjski ravnini. Skladnost in razlike ugotavlja v okviru besednozvezne, stavčne in medpovedne skladnje. Raziskave se je lotila z namenom, da bi ugotovila, v kolikšni meri hrvaška prevoda še zrcalita skladenjsko odvisnost slovenskih predlog od nemškega jezika (Orel 2019: 185).

6 Avtorica obravnava razmerje med besedilom, »ki je bilo umetelno izoblikovano v skladu s svojim namenom, položajem v knjigi (uvod, pojasnilo in motivacija za branje in doumevanje Biblije) in veljavnimi ubesedovalnimi pravili, ter med slovnico, ki jo je Bohorič po Melanchthonovih [...] predlogah latinske slovnice priredil za slovenščino« (Pogorelec 2011 (1986): 293).

7 Ahačič (2007: 283; 2008-2009: 93-94) npr. ugotavlja, da so slovenski protestantski pisci 16. stoletja poznali retoriko v teoriji in praksi, Pogorelec (2011 (1984): 269; 2011 (1986): 303) pa, da so pravila sočasne splošne stilistike ob hkratnem upoštevanju naravne slovenske dikcije ob Trubarju spoštovali tudi drugi slovenski protestantski pisci.

$8 \quad$ Prim. Seitz 1995: 472, tudi Orožen 1996: 152.

9 Na normativno izdelanost skladenjskega izražanja predhodne govorne bogoslužne oznanjevalne zvrsti slovenskega jezika na več mestih opozarja tudi M. Orožen (npr. 2008-2009: 319, 321).

10 O Katekizmu prim. Rajhman 1977: zlasti 21 in Ahačič 2009, o Abecedniku pa Ahačič 2008. Tudi Giesemann poudarja, da Trubarjev Katekizem ni enak predlogam Luthra in Brenza, pa tudi, da je Trubar besedila, ki jih je našel v virih, upošteval, hkrati pa tudi kombiniral, vendar »pri tem ni razvijal nobene lastne teologije« (Giesemann 2018: 188). 
raziskave.11 V njih odkrite enostavčne povedi - tako prave kot tiste, ki jih predstavljajo osamosvojljivi deli zloženih povedi in ki so (bile) uporabljene kot (pogojno veljavna) dokazila za oblikovno in vsebinsko tipologijo enostavčnih povedi - so obravnavane kot značilnost Trubarjevega in hkrati slovenskega knjižnega jezika 16. stoletja.

0.2 Preverjanje zajetosti enostavčnih povedi v prvih dveh Trubarjevih knjigah je pokazalo značilno sestavo: ob številčno močno prevladujočih zloženih povedih se pojavljajo redkejše enostavčne. Na razmerje, ki se ponavlja tudi v kasnejših in drugovrstnih Trubarjevih delih ter v Gmajn predgovori Dalmatinove Biblije (1584), do določene mere vpliva besedilni sestav,12 saj gre za verski priročnik (Katekizem), ki je po vsebini hkrati osnovni in zahtevnejši,13 ter za prvi in temeljni priročnik za učenje branja (Abecednik).

\section{TipologiJA ENOSTAVČNIH POVEDI}

1.1 Osnovno tipologijo enostavčnih povedi,14 pomnoženih s pastavčnimi,15 določa število izraženih stavčnih členov: sega od povedi z vsemi potencialnimi stavčnimi členi (tj. osebkom, povedkom, predmetom in prislovnimi določili (1. in 2. zgled); različico predstavljajo primeri, kjer je povedek sestavljen iz pomožnega glagola in povedkovega določila; prim. 3. zgled) do dvodelnih (4. zgled; v njem je osebek izražen z zaimkom) - med njimi so tudi taki, pri katerih je osebek, ki je navadno omenjen v bližnjem sobesedilu, izražen z osebno glagolsko obliko, 16 - ter glagolskih ali neglagolskih enodelnih različne dolžine (5. in 6. zgled). Kot enodelne povedi nastopajo tudi pogosto rabljeni in hkrati splošno uveljavljeni medmeti ali členki, npr. pole in amen (7. in 8. zgled). Prvi (pole) vzpostavlja tesnejšo povezavo z ogovorjenim in hkrati uvaja bodisi eno ali več enostavčnih povedi. Lahko pa se pojavlja kot osamosvojeni del večstavčne povedi, ki se uresničuje kot enostavčna. Drugi (amen) je s potrditvenim namenom zapisan na koncu besedila. 17 Npr.:

11 Prim. op. 4.

12 Analiza Trubarjevega pripovednega načina je npr. Pogačnika (1968: 138) usmerila k spoznanju, da so krajši stavki, s katerimi so misli zgoščeno izpovedane, predvsem značilni za Trubarjevo obravnavo teološke in kulturnozgodovinske snovi.

13 Prim tudi Ahačič 2009: 25.

14 Izbor je v prid izdelave veljavnejše tipologije mestoma razširjen z vsebinsko osamosvojljivimi deli večstavčnih povedi. Postopek do določene mere upravičuje tudi raba večfunkcionalnih ločil (npr. poševnice), ki so v okviru zložene povedi lahko uporabljena bodisi kot vmesno ali končno ločilo: ločujejo dele povedi ali zaznamujejo njen konec. Na razlikovalno rabo ločil v primerjavi z današnjo npr. opozarja Novak (1983/84: 183).

15 O pastavčnih povedih (členkovnih, medmetnih in zvalniških) kot vrsti enostavčnih prim. npr. Toporišič 1992: 175; 2000: 489).

16 Npr.: Proffite fprauo vero vedan fa vfo kerfzhansko Cerkou inu tudi fa me. (TC 1550: AIIIIb).

$17 \quad \mathrm{SSKJ}^{2}$ ga besednovrstno opredeljuje kot členek. 
[1] Ieft fem/le te ftuke is fuetiga pifma (inu nih islage vte peifni fhlofhene) [...] vle te buquice/ puftill prepifati vnalh iefig/ Bogu na zhaft inu hdobrumu vfem mladim tar preproftim ludem nafhe defhele. (TC 1550: AIIIa);

[2] TO nafho prauo kerszhansko Vero fo ty duainaift fueti Iogri nafhiga Gofpudi Iefufa Chriftufa is fuetiga Duha inu pifma vkupe flufhili/ (TC 1550: BVIb);

[3] Ieft fem le an vnuzen hlapez Luce. XVII. (TC 1550: 241);

[4] Molymo vfi. (TC 1550: 197);

[5] Ozha. (TA 1550: AVb) - Syn. (TA 1550: AVb);

[6] Ta Perue Chor. (TC 1550: 182) - Ta Drugi Chor. (TC 1550: 183);

[7] Pole mui hlapiz (per tim hlapci faftopi Iefufa/ kir ye bogu fpokorfzhimo/ inu nam fuyo martro flufhill) ye ner ta fauer/heni molh/ (TC 1550: 87);

[8] Tako Vero nam dai/ ozha nebelhki/ fa uolo fuiga lubiga Synu Iefufa Chriftufa/ fkufi fuetiga duha/ timu bodi vfa zhaft inu huala dana/ imer tar vfelei/ Amen. (TC 1550: 243).

V uvodni, nagovorni enostavčni povedi (VSEM Slouenzom/ Gnado/Myr/Mylhoft inu prauu Spofnane bofhye/ Jkufi Iefufa Chriftufa proffim. (TC 1550: AIIIa)) v TC 1550 so z različnimi stavčnimi členi izpostavljeni vsi trije osnovni akterji: Slovenci, ki jim je delo namenjeno (VSEM Slouenzom), s prvoosebno glagolsko obliko v vlogi povedka (proffim) Trubar kot avtor besedila, s prislovnim določilom vršilca dejanja ( $/ k u \int i$ Iefufa Chriftufa; Toporišič 2000: 625) pa božja oseba, ki lahko Slovencem kot prejemnikom podeli zaprošeno (Gnado/Myr/Mylhoft inu prauu Spofnane bofhye). Predložna zveza v vlogi prislovnega določila je posneta po nemščini.18 Iz zgleda je razvidna tudi priredna sestava predmeta, v okviru katere je le zadnji člen pridružen z veznikom inu.

Med izrazne različice predmeta spada tudi nedoločnik ob glagolu reči: Potle rezhe Iefus tim Iogrom pryti na ano Goro te Galileifke defhele/ (TC 1550: 41).

$\mathrm{V}$ okviru dialoga, ki s poučevalnim namenom poteka med očetom in sinom, je v TA 1550 mogoče zaslediti kot odgovore enostavčne povedi z izpuščenim osebkom ali povedkom. Informativnost z izpustom ni okrnjena, saj je manjkajoči stavčni člen znan oz. prepoznaven iz vprašanja. Npr.: Ozha. Kai ye ta Vezherya oli Mafha Iefufa Chriftufa nafhiga Gofpudi. Syn. ye an Sacrament oli ana Suetyna/ inu anu Jnamine te gnade bofhye [...] (TA 1550: 28).

1.1.1 Skupina enodelnih enostavčnih povedi je v prvih dveh Trubarjevih delih tipološko (oblikovno in funkcionalno) najbolj raznolika. Večje število tovrstnih povedi nastopa v naslovni, besedilnorazčlenjevalni, hkrati pa v vsebinskonapovedni vlogi. Zanje je značilna jedrnatost, zato so (tudi pri dvodelnih povedih; 1. zgled) pogosto

$\overline{18}$ Več potrditvenih primerov za tovrstno skladenjsko usklajenost z nemško prevodno predlogo je mogoče najti že s primerjavo Matevževega evangelija (TE 1555) kot prvega Trubarjevega novozaveznega prevoda in Lutrove prevodne predloge. Npr.: Inи oni nети pouedo, Vbetleemu vti Iudouski desheli, Sakai taku ie pifanu skufi tiga preroka (TE 1555: 3) - Vnd fie fagten jm/Zu Bethlehem im Jüdifchenlande/ Denn also ftehet gefchrieben durch den Propheten (LB 1545: $\mathrm{CCXLVb).} \mathrm{Na} \mathrm{primere} \mathrm{skladenjske} \mathrm{navezave} \mathrm{na} \mathrm{nemščino,} \mathrm{ki} \mathrm{posebej} \mathrm{izstopa} \mathrm{tudi} \mathrm{v} \mathrm{primerjal-}$ no-razvojnem pregledu rabe prostega stavka v slovenskem knjižnem jeziku, opozarja Pogorelec (1968: 148). 
opuščeni informativno nenujni stavčni členi. Najpogosteje je opuščen povedek (2., 3. in 4. zgled). Med tovrstne primere sodijo tudi (v 1.1 že omenjene) enobesedne naslovne navedbe udeležencev pogovora (5. zgled), ki je z zastavljanjem vprašanj $(\mathrm{Ozha})$ in z odgovori nanje (Syn) namenjen seznanjanju z osnovami krščanskega nauka in utrjevanju njihovega poznavanja. Npr.:

[1] Bug ye to kazho preklell. (TC 1550: AVIIIa);

[2] Suetiga Petra vuk od Gofpofzhine. (TC 1550: 130);

[3] Ana kratka iflaga te Vere. (TC 1550: 157);

[4] Ta Druga Sapuuid. (TC 1550: BVa);

[5] Ozha. (TA 1550: AVb) - Syn. (TA 1550: AVb).

Tesno vsebinsko povezanost v okviru dialoga npr. napovedujeta tudi zaporedna besedilna razdelka, ki ju uvajata naslova Vpra/hane od tih dobrill[!]19 dell. (TC 1550: 107) in Odguuor. (TC 1550: 108): prvi je besednozvezni, drugi enobesedni.

V podobnem razmerju sta tudi naslova, ki kažeta na delitev vlog pri litanijah: Ta Perue Chor. (TC 1550: 182) in Ta Drugi Chor. (TC 1550: 183): prvi nagovarja Boga (npr. O Gofpud Bug ti ozha nafh (TC 1550: 182)) ali natančneje opredeljuje tiste, ki prosijo (npr. My vfi reuni bofi grefhniki te proffimo. (TC 1550: 186)), uvaja ali konkretizira prošnjo z navedbo zaprošenega (npr. Dai myr tar fprauo vfem kralem inu viudom. (TC 1550: 188)), jo utemeljuje (npr. Sa uolo tuiga fuetiga roiftua (TC 1550: 184)), 20 drugi izreka tipizirane prošnje, kakršne so npr. Vflifhi nas lubi Gofpud Bug. (TC 1550: npr. 187, 189, 194), Vflifhi ti nas. (TC 1550: 181, 196), Smilife zhes nas. (TC 1550: 194), Obarri nas lubi Gofpud Bug. (TC 1550: 185), Pomagai nam lubi gofpud bug (TC 1550: 185) itd. Zbora si delita vloge tudi tako, da prvi zbor izreka to, pred čimer naj bi bili obvarovani, drugi pa stavčno izraženo prošnjo: Ta Perue Chor. (TC 1550: 184) npr. Pred to fylno Turfko Voifko (TC 1550: 184) in Ta Drugi Chor. Obarri nas lubi Gofpud Bug. (TC 1550: 185). Oba dela - uvodni in zaključni - vsebinsko sodita v okvir iste enostavčne povedi, čeprav sta zaključena s piko kot končnim ločilom.

Med oblikovno-pomenske različice enostavčnih povedi sodijo tudi nagovorni tipi s poimenovanjem naslovnika:21 poleg neposrednega samostalniškega nagovora (1. in 2. zgled) tudi različice $\mathrm{z}$ uvajalnim medmetom (3., 4. in 6. zgled), ki stopnjuje čustvenost nagovora, ter z izpostavljenim stavčnim členom v obliki zaimka (5. zgled). Povečano stopnjo čustvenosti zagotavlja tudi ustrezna izbira prilastka (npr. ljubi v prvem zgledu), v še večji meri pa povezava prvoosebnega svojilnega zaimka in manjšalnice Mui Synkuui (2. zgled). Nagovor uvaja bodisi enostavčno poved (6. zgled), pri večini tovrstnih primerov pa večstavčno (npr. 1., 2., 4. in 5. zgled), ki omogoča nadaljnje osamosvajanje posameznih enostavčnih

19 S klicajem, dodanim v oglatem oklepaju (dodala M. M.), je opozorjeno na napako v besedilu.

20 Utemeljitvi sledi prošnja, ki jo izreka drugi zbor: Pomagai nam lubi gofpud bug (TC 1550: 185).

21 Slovenska slovnica tovrstne primere obravnava v okviru soredja (Toporišič 2000: 490). 
povedi. V tretjem zgledu nagovoru sledi pričakovana, tipizirana prošnja prav tako v obliki enostavčne povedi. Npr.:

[1] LVbi kerszheniki/ Ieft fem/ le te ftuke is fuetiga pifma (inu nih islage vte peifni fhlofhene) katere vfaki fastopni zhlouik/ kir hozhe vnebu pryti ima veiditi inu derfhati/ htim tudi to litanio inu ano pridigo/ vle te buquice/ puftill prepifati vnafh iefig/ Bogu na zhaft inu hdobrumu vfem mladim tar preproftim ludem nafhe defhele. (TC 1550: AIIIa);

[2] Mui Synkuui/ letu ieft vom pifhem/ de ne grefhite/ (TC 1550: 104);

[3] O nebefki lubi ozha/ Imilife zhes nas fa uolo tuiga lubiga Synu Iefufa Chriftufa nafhiga gofpudi [...] (TC 1550: 199);

[4] O Vfigamogozhi dobrutliui Bug/ an vezhni ozha nafhiga gofpudi Iefufa Chriftufa/ kir fi fe is tuye velike milofti tim zhlouekom dall nafnane/ inu kir fi tuiga lubiga Synu Iefufa Chriftufa nafhiga gofpudi famiga poflufhati porozhill/ fakai ti fred ftuyem Synum inu fuetim Duhum fi vfe rizhi ftuarill inu fam obderhilh/ Smilife fmilife tudi zhes nas boge Slouence/ (TC 1550: 198);

[5] VY muy lubefniui bratye inu feftre/ (TC 1550: 67);

[6] ANa Pridiga/ zhes te Chriftufeue befede/ O Shena/ uelika ye tuia Vera (TC 1550: 202).

1.1.2 Iz doslej navedenih zgledov je razvidno, da je v okviru pripovednih enostavčnih povedi (Toporišič 2000: 515) ugotovljivih več vsebinsko različnih tipov. Enega izmed njih predstavljajo razlagalne oz. pojasnjevalne povedi (1. in 2. zgled),22 ki se jim pridružuje tudi t. i. definicijski tip23 (3. zgled). V njihov okvir sodijo tudi že omenjene, oblikovno raznovrstne naslovne povedi. V razdelku DECALOGVS,24 kjer je predstavljenih deset zapovedi, vsako enoto posebej naslovno uvaja številčno poimenovana zapoved (4. zgled), vendar so tudi nekatere napovedi sestavni del zloženih povedi. V razdelku SYMBOLVM Apoftolorum. (TC 1550: BVIIb) - s slovenskim naslovom Letu fo ty ftuki kerfzhanfke Vere od tih Iogrou poredi flofheni. (TC 1550: BVIIIa) - so naslovno napovedani členi vere. Tem se v novi vrstici pridružuje ime apostola kot domnevnega avtorja člena (5. zgled), kar daje slutiti, da gre za ločeni informaciji. Vsaki številčni napovedi sledi navedba ustreznega člena apostolske vere. Členi so zaporedno navedeni v posebnih vrsticah, zamejeni s piko, tudi v primerih, kadar je njihova stavčna struktura zaradi tesne vpetosti v sobesedilo izraziteje okrnjena. Npr. Ta Perue ftuk25 | Sueti Peter. | IEft veryo Vbuga Vozho Vjigamogozhiga/ Stuarnika nebes inu femle. | Ta Drugi ftuk | S. Andrei. | Inu Viefufa Chriftufa Synu nega diniga Gofpudi nafhiga. (TC 1550: BVIIIa). Posebno različico pripovednih enostavčnih povedi predstavljajo povedi, začete $\mathrm{z}$ vprašalnicami, ki pa ne uvajajo vprašanj (6. zgled z dvema primeroma). Na njihov pripovedni značaj - napovedujejo sledečo vsebino - opozarja tudi na koncu dodana pika (6. in 7. zgled). Tudi te povedi so pogosto skladenjsko okrnjene. Zgolj na

22 Novak (1983/84: 184) jih npr. poimenuje »označevalne stavke«. Za ponazorilo navaja priredje: Biblia je ena gerčka beseda, inu poméni v'gmajn, te Bukve, Stariga inu Noviga Testamenta.

23 Prim. Pogorelec 2011 (1972): 247, ki isto (vzorčno navedeno) enostavčno poved v skladu z retoričnimi pravili, uveljavljenimi v 16. stoletju, v okviru analize retorične urejenosti odstavka iz TC 1550 opredeljuje kot »definicijo«. TV fo te defed fapunidi bofhyel te ifte tudi Moifes pifhel (TC 1550: BIVa). Pokončnice, ki razmejujejo vrstice, dodala M. M. 
samostalniški del okrajšano (enodelno) enostavčno poved pripovednega značaja predstavlja tudi naslovno napovedani odgovor na predhodno vprašanje (8. zgled). Kratkost oz. jedrnatost odgovora je tudi v tem primeru zgovoren dokaz in hkrati posledica tesne vsebinske povezanosti dialoga. Npr.:

[1] Tu Ime/ Adam/ pomeni zhlouik/ [...] (TC 1550: BIb);

[2] ne profli vezh fuetnikou de bi fan proflili/ temuzh ferznu tar vefelu/ fam ftopi pred Buga/ inu praui gnemu/ Abba Pater Ro. viii. (tu ye) Mui Atel/ Mui lubi Ozha/ pomagai/ oli dai meni tu oli tu. \&c (TC 1550: 235);

[3] TA Molytua/ ye an rifnizhin ferzhan inu priatliu fguuor Sbugom/ tu ye [...] (TC 1550: 16);

[4] Ta Druga Sapuuid. (TC 1550: BVa);

[5] Ta Perue ftuk | Sueti Peter. (TC 1550: BVIIIa);

[6] Kai ye ta Molytua/ Du inu koku fe ima Molyti. (TC 1550: 16);

[7] Kai nam pag ty Sacramenti pomenuio. (TC 1550: 62):

[8] Kai nas pag ima perganati de my dobru deimo/ Bogu flufhimo/ inu de fe greha varuyemo? | Odguuor. | Try rizhi (TC 1550: 117).

1.2 Nadaljnje funkcionalno utemeljeno tipološko členjenje enostavčnih povedi upošteva različno sestavo besednozveznih stavčnih členov, ki je priredna ali podredna. Priredne pare in nize je mogoče zaslediti pri vseh stavčnih členih: osebku (1. in 2. zgled), predmetu (3. in 4. zgled), prislovnih določilih (7. zgled) in povedkovem določilu (5. in 6. zgled), zaznati pa jo je mogoče tudi v okviru levega ali desnega prilastka (5. zgled) oz. v okviru podrednih sestavin stavčnih členov. Dvo- ali veččlenski naštevalni nizi so $\mathrm{v}$ dosedanjih skladenjskih raziskavah navadno obravnavani in predstavljeni kot dvojne oz. trojne formule. 26 Veljajo za opazen, nepogrešljiv, pomensko razvejan stilizem protestantskega knjižnega jezika. V okviru enostavčnih povedi je $\mathrm{v}$ skladenjsko različnih vlogah mogoče zaslediti tudi (stilno učinkovite) ponovitve istih besed27 (9. zgled). Npr.:

[1] AN Scoff oli Far ima byti pres tadla/ an molh ane fhene/ trefiu/ ane praue dobre myfli polhten/ kir rad ludi herperguye [...] (TC 1550: 126); 28

[2] Kerfzhouati inu te verne fpifhati ftellom tar fkryo Iefufouo/ nam nafha ferza fpet hdobrumu premeni/ (TC 1550: BVIIb);29

[3] VSEM Slouenzom/ Gnado/ Myr/ Mylhoft inu prauu Spofnane bofhye/ fkufi Iefufa Chriftufa proflim. (TC 1550: AIIIa);

[4] Ieft veryo tudi Viefufa | Vtiga prauiga Chriftufa | Vfynu bofhyga diniga | [...] (TC 1550: 159);

26 O raziskanosti dvojne in trojne formule (ter kopičenja kot sorodne retorične figure) $\mathrm{v}$ jeziku slovenskih protestantskih piscev 16. stoletja prim. Ahačič 2007: 302-304; Ahačič 2008-2009: 96-97. Avtor posebej izpostavlja raziskovalni dosežek E. Seitz, ki v primerjalno zasnovani raziskavi dvojične prirednosti $\mathrm{v}$ Trubarjevih besedilih odkriva štiri pomenske skupine parov, povezanih z inu (Seitz 1995).

27 Toporišič (2000: 528) tovrstne ponovitve uvršča med skladenjska sredstva za izražanje stopnjevitosti.

28 Zgled enostavčne povedi zagotavlja osamosvojeno navedeni izhodiščni del večstavčne povedi.

29 Zgled kaže na priredno nedoločniško zvezo v vlogi osebka (Toporišič 200: 399-400). 
[5] Tu ime pag/ Iefus/ vtim flouenfki iefiki fe praui/ an ohranik/ oli Ifuelyzhar: oli an Pomozhnik [...] (TC 1550: 91); 30

[6] Tu zhlouefku ferze ye hudu tar ifkafhenu. (TC 1550: 77);

[7] Lubi Gofpudi Boga tuiga/ is celiga tuiga ferza/ is cele tuye dufhe/ inu is cele tuye myfli/ inu is cele tuye mozhi. (TC 1550: 143);

[8] Glih taku fhe fdai/ fuio Cerkou te kerfzhenike ftrafa/ Imogetero rizho/ koker Sturki/ fdragino/ fhlifami/ fzhudnimi bolefanmi/ fhudo gofpofzhino/ drufhino inu fofefzhino/ fhudimi Scofi/ fari/ Menihi inu fdrugo nefrezho/ (TC 1550: 218-219);

[9] Rifnizhnu rifnizhnu ieft vom poueim/ kateri poflufha muyo befedo/ inu timu veryame kir ye mene poflall/ ta ima ta vezhni leben/ (TC 1550: 96-97).

V predzadnjem (osmem) zgledu je naštevalni niz veččlenskega prislovnega določila načina poenoten tudi s ponavljanjem predloga. Slednji se v skladu z oblikujočo se pravopisno normo pri istovrstnih enotah občasno opušča. Pri samostalniku fhlifami je pričakovano pisno prekriven z začetkom besede. ${ }^{31}$

1.2.1 Samostalniškim delom enostavčnih povedi, zlasti osebku in predmetu oz. predmetom, se običajno pridružujejo levi in desni prilastki z dokaj ustaljeno razvrstitvijo: levi (ujemalni) pridevniški in desni (neujemalni) samostalniški. Pogoste pa so tudi podredno ali priredno razširjene prilastkovne zveze. Npr.: O nebefki lubi ozha/ fmilife zhes nas fa uolo tuiga lubiga Synu Iefufa Chriftufa nafhiga gofpudi/ [...] (TC 1550: 199).

1.2.1.1 Ker so sestavni del katekizma tudi osnovna verska besedila - med njimi apostolska vera, deset zapovedi, očenaš, litanije -, kjer h govorni učinkovitosti in lažji (za)pomnljivosti vsebine prispevajo tudi stilne figure, je pričakovana tudi na govorno izročilo in pridigarsko tradicijo vezana, od običajne odstopajoča, hkrati pa stilno učinkovita, nevsakdanja besednoredna razvrstitev sestavin enostavčnih povedi. Med že opažene, večkrat omenjane značilnosti Trubarjevega jezika spadata inverzija prilastka (1. in 2. zgled), ki jo je mogoče zaslediti že v uvodni povedi Katekizma v vlogi blagoslovitvene formule (1. zgled), in končna stava glagola (3. zgled). Npr.:

[1] VSEM Slouenzom/ Gnado/ Myr/ Mylhoft inu prauu Spofnane bofhye/ fkufi Iefufa Chriftufa proflim. (TC 1550: AIIIa);

[2] Sapuuid bofhya Adamu inu Eue dana. (TC 1550: AVIb);

[3] Nu fdai pag hozhmo/ od te Shege inu milli/ tiga Verniga zhloueka/ gouoriti. (TC 1550: 213).

Pregled inverzij prilastka v enostavčnih povedih je pokazal, da se nekateri prilastki pogosteje pojavljajo zapostavljeno (npr. božji: gnada božja, beseda božja, štrafinga božja, zapoved božja ${ }^{32}$ ), kar daje slutiti proces terminologizacije oz. že terminolo-

30 Zgled je osamosvojeno navedeni prvi stavek priredja.

31 V podobne nize istopredložnih zvez je pogosto zajet tudi predlog $v$-. Neweklowsky (1995: 318) v Trubarjevem Katekizmu (1550) odkriva 18 primerov njegovih podvojitev, kar se je pokazalo kot pravopisna posebnost zgodnejšega obdobja Trubarjevega ustvarjanja, saj pregled Pisma Rimljanom (1560) ni odkril nobenega tovrstnega primera. 
giziranost besednih zvez.33 Zgled Shegen tiga fakona/ htimu fakoni pomuzhi fo vee rizhi ftuaryene inu poduer/hene. (TC 1550: AVIa), ki zajema dve zaporedno nanizani enostavčni povedi, kaže na inverzijo desnega prilastka. Slednja ima za posledico težjo razumljivost primera ( $h$ pomoči timu zakoni $\rightarrow$ htimu fakoni pomuzhi).

Končna stava osebne glagolske oblike, deležniškega dela povedka ali nedoločnika je v pesmih običajno pogojena z rimo (1. zgled). ${ }^{34}$ Slednja lahko vpliva tudi na izbiro krajše oblike glagola (2. zgled), občasno pa celo na rabo odstopajoče časovne oblike, kar je posebej razvidno iz osamosvojljivih delov zloženih povedi (3. zgled). Npr.:

[1] Kadar ye Iefus vnebu fhall | ye gfuym iogrom rekal | Meni ye bug vfo oblaft dall | Meni ye vfe poduergal (TC 1550: 168[=170]);

[2] Sueti Paul venim lifti | Inu ty Euangelifti | Odpraue Mafhe pifho | Kadar ye Iefus fratan bill | Sa nas Martro fterpit hotill | Siogri gre vuezher vhifho (TC 1550: 174);

[3] Sazhne fhnimi vezheryati | Inu nim noge vmiuati | Dolgu nim pridiguye | Od Buga/ od Martre fuye | Vfe fuye Verne trofhtall ye | Molyt lubit vkafuye. (TC 1550: 175).

1.2.1.2 Nekaj retoričnih figur (npr. simetrično realiziran hiazem) ${ }^{\mathbf{3 5}}$ se običajno razkriva le v zloženih povedih (1. zgled), v enostavčnih pa le izjemoma (2. zgled). Med retoričnimi figurami je tudi v TC 1550 že opazna poudarjalna razdružitev dvojne formule z vmesnim pag (3. zgled). 36 Npr.:

[1] INu Bug ye ftuarill zhloueka po fuyem pildu/ po Bofhy Stalti ga ye fturill/ mofha inu fheno ye ftuarill inu ye Bug obba fhegnall/ inu ye rekall. (TC 1550: AVIa);

[2] Ta praua Vera/ inu befeda bofhya/ moraio vfelei byti vkupe/ (TC 1550: 211);

[3] Sa telefne pag inu pofueidtne rizhi/ [...] imamo tudi vpokuri inu vueri profliti/ oli pag vti vifhi/ (TC 1550: 21).

1.2.1.3 Med enostavčnimi povedmi, uporabljenimi v obeh Trubarjevih knjigah iz leta 1550, se pojavljajo tudi take, ki kažejo bodisi na obstoj ali na oblikovanje stilno oz. retorično učinkovitih obrazcev. Mednje sodijo blagoslovitvene formule in tipizirane prošnje, ki so v okviru posameznih besedilnih enot dodane bodisi uvodno (1. in 2. zgled) ali sklepno (3. in 4. zgled). V tej vlogi v Katekizmu in Abecedniku npr. nastopata tudi uvodni enostavčni povedi.

33 Na številčnost terminoloških besednih zvez (npr. pravi krščeniki, božja beseda in beseda božja), ki se v primerjavi s predhodnim obdobjem kaže kot ena od značilnosti jezika slovenskih protestantskih piscev 16. stoletja, opozarja A. Legan Ravnikar (2008: 27-28) in hkrati navaja, da je izmenjava levoprilastkovne rabe z desno pogosta. Prim. tudi Orožen 2008-2009: 325-326.

34 V proznih prevodnih besedilih pa je tudi na besedni red in umeščanje glagolskih oblik pogosto vplivala tujejezična prevodna predloga, čeprav so protestantski pisci od Trubarja dalje hkrati upoštevali tudi skladenjske vzorce govorjenega jezika. Na oboje je bilo že večkrat opozorjeno (npr. Orožen 1996: 234-248; Merše 2013: 107-109, itd.).

35 Med retoričnimi figurami, opaženimi ob analizi izbranega odlomka iz TC 1550, ga npr. omenja Pogorelec (2011 (1972): 247-248).

36 Isti zgled navaja B. Pogorelec (2011: 249-250) v sklopu prikaza retorične zgradbe odstavka kot izbrane besedilne enote. Figuro poimenuje hiperbaton (po Susenbrotus 1576). 
Gre za prošnjo, ki je hkrati primer uvodne blagoslovitvene formule (1. in 2. zgled). Uvodnim podobne formule so uporabljene tudi na koncu posameznih poglavij oz. besedilnih enot (3. zgled). Npr.:

[1] VSEM Slouenzom/ Gnado/ Myr/ Mylhoft inu prauu Spofnane bofhye/ Ikufi Iefufa Chriftufa proflim. (TC 1550: AIIIa);

[2] Vfem Mladim inu Preproftim Slouenzom/ Mylhoft bofhyo inu to vezhno dobruto od Ozheta nebefkiga vtim Imeni Iefufa Chriftufa proflim. (TA 1550: AIIa);

[3] Obtu vuzhimo fe/ le te ftuke nafhe praue vere/ [...] Inu timu famimu tudi bodi vfelei vfa zhaft Amen. (TC 1550: AIIIIb);

[4] Htimu inu vfimu dobrumu dai Iefus Chriftus fuyo gnado/ AMEN. (TA 1550: AIIIa).

1.3 Enostavčne povedi se medsebojno razlikujejo tudi glede na vrsto uresničenega skladenjskega razmerja med povedkom in osebkom, ki predstavljata jedro pomenske podstave dvodelnih povedi. Osnovno razliko povzroča izbira tvornega (1. zgled) ali trpnega načina, saj se z njo vloge delovalnikov zamenjajo: osebek tvornega stavka se v trpnem pretvarja v prislovno določilo vršilca dejanja (2. zgled) ali pa se sploh ne omenja (3. zgled), predmet iz tvornega stavka pa v trpnem dobiva vlogo osebka (Toporišič 2000: 358). Npr.:

[1] Bug ye to kazho preklell. (TC 1550: AVIIIa);

[2] Tu ime Iefus ye nemu od tiga angela Gabriela pred nega pozhedtuo danu/ (TC 1550: 90) ( $\leftarrow$ angel Gabriel mu je dal ime);

[3] Ta Molh ye taku ftuaryen. (TC 1550: AVa).

1.3.1 Nekaj enostavčnih povedi iz prvih dveh Trubarjevih knjig izkazuje ujemalne in vezljivostne posebnosti. Pri prvih gre za odstopanje od pričakovanega ujemanja povedka z osebkom po osebi, številu, spolu in sklonu. $37 \mathrm{Npr}$.: Od koga inu fakai ye ta pridiga inu ta kerft poftaulen. (TC 1550: 169). Zgled kaže, da se deležniško povedkovo določilo po spolu in številu ujema le z zadnjim členom priredne samostalniške dvojice, ki v trpniku opravlja vlogo osebka. Podobno velja tudi za povedek v primeru Meffu inu kry/ nei tebi tiga dallu nafnane/ temuzh mui ozha/ [...] (TC 1550: 209-210), kjer se povedek po spolu in številu prilagaja prvemu členu priredno zloženega osebka. V zgledu Ta praua Vera/ inu befeda bofhya/ moraio vfelei byti vkupe/ (TC 1550: 211) je povedek v množini, ki se pogosto uporablja namesto pričakovane dvojine. $38 \mathrm{Na}$ osnovi izhodišča zloženega stavka osamosvojena enostavčna poved kaže na odpovedovanje usklajenosti po spolu v okviru daljše povedi: Te Iefufeue befede pag (katere ner vezh gouore le od odpufhzhane tih

37 B. Pogorelec (2011 (1986): 298-299) navaja figure, ki urejajo ujemanje, npr. primere zevgme (ujemanje z bližnjim osebkom v spolu, številu in osebi) ter silepse (gre za prilagajanje po spolu, številu, osebi in sklonu prvini, ki v zvezi prevladuje po kateri od svojih pomenskih (ali pomensko-slovničnih) lastnosti), iz Bohoričeve slovnice (deloma na osnovi primerjave Bohoričeve slovnice in Melanchthonove predloge).

38 Na nekaj ujemalnih posebnosti glede spola in števila, zaznanih v okviru analize rabe pomožnega glagola biti, je bilo že opozorjeno (Merše 2017: 222). Namensko in problemsko širše je bila tipološko predstavljena tudi postopna pluralizacija dvojine (Jelovšek 2016: zlasti 98). 
grehou vftanena tiga fhiuota inu tiga vezhniga lebna) te fo gar fdoftimi inu fuelikimi zaihni poteryeni/de na tih oben zhlouik ne ima zbiuulati. (TC 1550: 105).

Med enostavčnimi povedmi, ki so bile neposredno ali posredno odkrite v prvih dveh Trubarjevih knjigah, so tudi take, ki vključujejo ogovorni osebni zaimek vi. Slednji je glede spola in števila samostalnika, ob katerem stoji, neinformativen. $39 \mathrm{~V}$ prvem zgledu je nagovorni zaimek moškega spola, nagovorjena oseba pa ženskega, v drugem pa je ujemanje polno. Npr.:

[1] Sueti Peter taku uely/Vy thene bodite pokorne valhem molhem/ [...] (TC 1550: 134);

[2] VY Hlapci inu Slufhabniki/ bodite pokorni valhim telefnim gofpudom/ ftrahom inu ftrepetanom vti preprofhzhini vafhiga ferza/ [...] (TC 1550: 140).

1.3.2 Nekaj značilnosti se nakazuje tudi glede izbire časovnih oblik. Za naslovne in definicijske tipe enostavčnih povedi je dokaj običajna izbira sedanjika s splošno veljavnim pomenom. $\mathbf{4 0}$ Ker je neujemalnost glede izbire časovnih oblik praviloma razvidna le iz zloženih in večstavčnih povedi oz. vezana nanje (npr. Sueti Peter Actorum iiii. taku pryzhuie vtim meifti Ierufalem pred Anafhom Papefhom inu pred Caifafhom Scofom inu pred vemi vifhimi Duhoufkimi tar Defhelfkimi inu ye giall/ (TC 1550: 100)), je ustreznost izbrane časovne oblike praviloma treba preverjati sobesedilno, torej zunaj meja enostavčnih povedi.

1.4 Pomensko oz. funkcijsko tipologijo enostavčnih povedi znatno razširjajo oblikovne in hkrati pomenske različice, pogojene z izražanjem skladenjskega naklona (povednega, vprašalnega, velelnega, pa tudi želelnega in pogojnega). ${ }^{41}$

1.4.1 Prevladujejo pripovedne enostavčne povedi, ki izkazujejo več (v 1.1.2 že omenjenih) vsebinskih oz. funkcijskih različic: poleg navadnih pripovednih (1. zgled) obstajajo še funkcijske različice, ki jih predstavljajo t. i. definicijske oz. pojasnjevalne povedi, nastopajoče v naslovni vlogi, v vlogi verza (2. zgled) itd. Npr.:

[1] My fmo po naturi ani otroci tiga ferda/ koker ty drugi. (TC 1550: 79);

[2] Vrag feime vpeto vgrifne. (TC 1550: 150).

1.4.1.1 Več pripovednih enostavčnih povedi izkazuje čustveno obarvanost. Ta se pogosto veže na nagovor, razodevata pa jo predvsem izbira prilastka in pogosta prisotnost medmeta (prim. 1.1.1), občasno pa tudi druga sredstva. K čustvenosti pripovednih

39 O rabi nepodaljšanega drugoosebnega zaimka vi in njegove podaljšane različice vidva $\mathrm{v} 16$. stoletju prim. Jelovšek 2016: 97-102.

40 Na pogosto Trubarjevo uporabo dovršnega sedanjika pri izražanju preteklih dejanj (npr. v evangelijskih povzetkih (1555 in 1581-82)) na več mestih opozarja tudi Orožen (npr. 2008/2009: 322). Prim. tudi Merše 2009: 53.

41 O delni prekrivnosti glagolskega in skladenjskega naklona $\mathrm{v}$ slovenskem jeziku prim. Toporišič 1982: 259-260; 2000: 514. 
enostavčnih povedi znatno prispevajo tudi izbrani izrazi in besedne zveze, ki izstopajo po ekspresivnosti, posredno pa npr. tudi jedrnatost samoobtožbe. Npr.: Ieft fem le an vnuzen hlapez Luce. XVII. (TC 1550: 241).

1.4.2 Zlasti iz izbire glagolov (1. zgled) in njihovih oblik (npr. velelnika in pogojnika; 2. zgled) v povedkovni vlogi ter iz povezav naklonskih glagolov z nedoločniki (3. zgled) je prepoznavnih več naklonskih odtenkov, npr. pogojnosti, zaželenosti ali zahtevanosti dejanja. Zgledi kažejo tudi na vsebinsko raznolikost želja. Različne stopnje so posledica približanosti bodisi zahtevi ali prošnji.42 Stavčno izražene prošnje oz. želje na koncu besedilnih enot (npr. uvoda (1. zgled), molitve, poglavij, katekizma (druga poved v okviru 2. zgleda)) so v veliki meri tipizirane (prim. 1.2.1.3). Npr.:

[1] Proffite fprauo vero vedan fa vfo kerfzhansko Cerkou inu tudi fa me. (TC 1550: AIIIIb);

[2] Tako Vero nam dai/ ozha nebefhki/ fa uolo fuiga lubiga Synu Iefufa Chriftufa/ fkufi fuetiga duha/ timu bodi vfa zhaft inu huala dana/ imer tar vfelei/ Amen. (TC 1550: 243);

[3] Nu fdai pag hozhmo/ od te Shege inu milli/ tiga Verniga zhloueka/ gouoriti. (TC 1550: 213).

1.4.3 Vprašalni naklon razodevajo vprašalne enostavčne povedi, prepoznavne po značilnih vprašalnicah (1. zgled), spremenjenem besednem redu (2. zgled), manj zanesljivo pa po vprašaju kot končnem ločilu, saj ga večkrat nadomešča pika (3. zgled), občasno pa celo večfunkcionalna poševnica. Za katero naklonsko različico gre, običajno razkrije upoštevanje širšega sobesedila. Pri četrtem zgledu gre za osamosvojeni del zložene povedi. Zgled za preurejeno besednoredno zaporedje vprašalne enostavčne povedi ponuja TA 1550 (5. zgled). Npr.:

[1] inu Gofpud Bug klyzhe Adama inu praui/ Kei fi? (TC 1550: AVIIb);

[2] Nei fo li te defed inu druge fapuuidi tudi befede bofhye? (TC 1550: 107);

[3] Sakai fi ti an kerfzhenik. (TA 1550: AVb);

[4] Potle bug gre fam vparadyfh [...] Rekall ti Adam fe boyfh? (TC 1550: 149);

[5] Ozha. Pred to Iedyo koku fe ima molyti? (TA 1550: BIIIIa).

1.4.4 Tudi izražanje velelnega naklona izkazuje v okviru enostavčnih povedi več odtenkov. Prepoznavni so sobesedilno, saj se klicaj kot značilno ločilo ne uporablja. Na različne hotenjske nianse (npr. zgolj hotenje, zahtevo, poziv, prošnjo itd.) kaže izbira različnih glagolov (npr. 1. in 6. zgled), nedoločniških zvez (2. in 7. zgled), na prepoved pa prisotnost nikalnice (5. zgled). Z velelniško obliko za drugo osebo ednine je pogosto izražena tudi velelnost za tretjo osebo, ki ima hkrati splošno veljavni pomen (3., 4. in 8. zgled). Npr.:

[1] Molymo vfi. (TC 1550: 197);

[2] Nu fdai pag hozhmo/ od te Shege inu milli/ tiga Verniga zhloueka/ gouoriti. (TC 1550: 213);

[3] Obtu vuzhimo fe/ le te ftuke nafhe praue vere. [...] Inu timu famimu tudi bodi vfelei vfa zhaft Amen. (TC 1550: AIIIIb) 'to naj bo čaščeno vekomaj';

42 Za katero različico gre, običajno razkrije upoštevanje širšega sobesedila. 
[4] timu bodi vfa zhaft inu huala dana/ imer tar vfelei/ Amen. (TC 1550: 243);

[5] Ne fheli lufkih then inu tudi polluu (TC 1550: 156);

[6] Pofhtui ozho inu Mater/ tu ye ta perua fapuuid kir ima to oblubo/ de delgu bolh fhiu/ inu de tebi dobru bode na femli. (TC 1550: 138);

[7] Natu ye ozha gfynu giall $\mid$ Ti morefh zhlouik byti $\mid$ De bodefh vragu fubper ftall (TC 1550: 149); $\mathbf{4 3}$

[8] Sahuali/ nim da/ praui | Is tiga vfaketeri py | Tu ye kelih muye kriy | Te muye noue fhafti | [...] (TC 1550: 176).

Med zahteve spadajo tudi zapovedi, ki sicer vključujejo tudi prepovedno različico. Npr.: Ta peta Sapuuid. Ne Vmori. (TC 1550: BVb). Z zanikanim velelnikom izražena prepoved v vlogi zapovedi odstopa od drugih po rabi dovršnika. Vzrokov za njegov izbor je lahko več: zavedanje, da je že enkratno dejanje nedopusten prekršek;44 manjša uveljavljenost ali uzaveščenost (predponsko tvorjenega) vidskega para moriti - umoriti $\mathrm{v}$ primerjavi s (priponsko tvorjenim) parom ubijati - ubiti (v obeh primerih nedovršnik izraža ponavljanje dejanja) ali zgolj neupoštevanje tudi v 16. stoletju že praktično uveljavljenega pravila, da se pri zanikanju namesto dovršnika uporablja nedovršnik. (Prim. Merše 1995: 210.) Nedovršno različico in $\mathrm{s}$ tem vidsko usklajenost $\mathrm{z}$ drugimi šestimi zapovedmi v obliki prepovedi uresničuje že Trubarjev Abecedarij (za njim tudi TC 1555). Npr.: Ta Peta.|Ti ne ima/h vbyati. (TA 1550: AVIIIb).

Tudi temelji za izražanje zapovedi z zvezo imeti + nedoločnik, prepovedi pa $\mathrm{z}$ zvezo ne imeti + nedoločnik, so bili oblikovani že z rabo v TC 1550. Primeri rabe glagola imeti kot polnopomenskega in kot pomožnega, naklonsko rabljenega glagola (v zvezah z nedoločnikom), uporabljenega v enostavčnih povedih v TC 1550, kažejo na širino njegovega pomenskega in slovničnega spektra: z njegovo pomočjo so izražene želje in zahteve (1. in 2. zgled), poudarjena nujnost (3. zgled), uporablja pa se tudi za izražanje prihodnosti, kar je mogoče ponazoriti z uvodnim stavkom priredja, pretvorjenim v enostavčno poved (4. zgled). ${ }^{45} \mathrm{Npr}$.:

[1] Brumni imamo byti [...] (TC 1550: 177);

[2] Drufih bogou ti ne imei (TC 1550: 153);

[3] Na lete Iefufeue befede/ inu poftauo te Pridige/ inu tiga Kerfta/ imamo my vfy dobru merkati/ (TC 1550: 34);

[4] Tu fhenfku Seme ima tebi kazhi tuyo glauo ftreti/ [...] (TC 1550: 83).

1.5 Z zgledi rabe enostavčnih povedi iz prvih dveh Trubarjevih knjig je mogoče opozoriti še na nekaj drugih, že znanih, pogosto omenjanih značilnosti Trubarjevega oz. slovenskega knjižnega jezika 16. stoletja. Opazna je npr. prisotnost informativno nenujnih zaimkov, še posebej v vlogi členov. Npr.:

43 Zgled je kot odgovor trdno sobesedilno včlenjen.

44 Dovršna različica je uporabljena tudi v pesemski obliki razlage desetih zapovedi: Varri zhloueka vnemori/h (TC 1550: 155).

45 O pomenskem obsegu glagola imeti, ki vključuje tudi podrobno razčlenjeno naklonsko rabo, v sodobnem slovenskem knjižnem jeziku prim. Vidovič Muha 2011: 307-343. 
[1] Ta Molh ye taku ftuaryen. (TC 1550: AVa);

[2] Na tu ye Gofpud Bug puftill pafti an fan/ na Adama/ (TC 1550: AVb);

[3] Tiga fdrauie te dufhe/ oli odpufzhane tih grehou/ inu te milofti bofhye/ fo vfi Verni/ od fazhetka tiga fueidta/ le per Iefufu Chriftufu ifkali Suero/ [...] (TC 1550: 232).46

Na vpliv nemščine, ki je za del zajetih besedil jezik predloge, 47 v okviru enostavčnih povedi kaže tudi nekaj značilnih predložnih zvez: v 1. in 2. zgledu je npr. v okviru trpniške strukture uporabljena zveza od koga, ki se uresničuje kot prislovno določilo vršilca dejanja; v 3. zgledu zveza skozi kaj v vlogi prislovnega določila sredstva itd. Tudi nekaj vezav s predložnimi skloni se ujema z nemškimi sopomenskimi vzporednicami (npr. pridiga čez kaj; 4. zgled). Npr.:

[1] Leta pridiga ye od primofa trubarie zheftu pridigouana/ (TC 1550: 202);

[2] Tu ime Iefus ye nemu od tiga angela Gabriela pred nega pozhedtuo danu/ Luce I. (TC 1550: 90);

[3] O nebefki lubi ozha/ [...] pofuezhui nas fkufi tuyo befedo ftuyem fuetim Duhum/ [...] (TC 1550: 199);

[4] ANa Pridiga/ zhes te Chriftufeue befede/ (TC 1550: 202).

2 Prikaz tipologije enostavčnih povedi, kakršno utemeljuje raba v prvih dveh Trubarjevih knjigah, se ujema z ugotovitvami, ki so jih prispevale raziskave skladnje in stavčnih tipov v Trubarjevih kasnejših, zlasti samostojnejših delih (npr. v povzetkih evangelijskih poglavij v njegovih novozaveznih prevodih (Orožen 20082009)), ter skladenjska opažanja ob analizi opomb v TPo 1595 (Merše 2011).48 Našteta besedila so bila raziskovalne pozornosti deležna predvsem zaradi svoje besedilnovrstne specifičnosti in $\mathrm{z}$ njo povezane namembnosti.

M. Orožen (2008-2009: zlasti 319-321) ugotavlja, da v strnjevalnih vsebinskih povzetkih poglavij iz Matevževega evangelija prevladujejo ekonomični stavčni vzorci. Ključne vsebine so večinoma ubesedene v enodelnih (glagolskih in neglagolskih) stavkih. Enostavčne povedi z vsemi predvidljivimi stavčnimi členi so - enako kot v prvih dveh knjigah - redke, pogosti pa so izpusti posameznih stavčnih členov. Tipologijo razširjajo tudi polstavki.49 Tudi za opombe v TPo 1595, ki imajo namen ustvarjati in olajševati pregled nad obravnavano vsebino, je značilno, da so kratke in informativno zgoščene, kar je usmerjalo k izbiri enostavčnih povedi. Med njimi je npr. zaradi pogostosti posebej opazen vprašalni stavek v ugotavljalni funkciji (npr. Kaj je ta pravi Vuk (TPo 1595: II,305)). Prevladujejo dvodelne enostavčne povedi. Pogosto so razširjene $\mathrm{z}$ dvojnimi formulami različnih tipov.

46 Kot enostavčna poved je prikazan začetni stavek priredja.

47 Podrobneje o Trubarjevem načinu prevajanja svetopisemskih odlomkov, zajetih v TC 1550, ter naslonjenosti na latinsko ali nemško predlogo prim. Ahačič 2009: 247-251.

48 Osnovni namen obravnave opomb v Trubarjevem prevodu Hišne postile je bil (na osnovi primerjave s prevodno predlogo) ugotoviti in predstaviti Trubarjeve prevajalske navade, kar vključuje prikaz obsega prevodne skladnosti ter najopaznejših jezikovno in stilno pogojenih oddaljitev od predloge (Merše 2009).

49 Npr. Eniga sludiem obdaniga fturi sdrauiga (CAP. XII) (Orožen 2008-2009: 24). 
3 Tipologijo enostavčnih povedi, kakršno oblikujejo primeri, izkazani v prvih dveh Trubarjevih knjigah, in kakršno potrjujejo skladenjske raziskave njegovih kasnejših del, je mogoče ocenjevati kot trdno sestavino Trubarjeve skladnje, s pomočjo katere je uspešno obvladoval raznovrstno skladenjsko problematiko ter druge ubesedovalne dileme, tako pri prevedenih kot pri samostojnih, zvrstno različnih delih iz bogatega ustvarjalnega opusa.

\section{VIRI}

LB 1545 = Martin Luther, Biblia: Das ift: Die gantze Heilige Schrifft / Deudfch / Auffs new Zugericht, Wittemberg, 1545.

SSKJ2 = Slovar slovenskega knjižnega jezika, druga, dopolnjena in deloma prenovljena izdaja, www. fran.si (dostop 6. 7. 2020).

TC 1550 = Primož Trubar, Catechifmus In der Windifchenn Sprach, Schwäbisch Hall, 1550.

TA 1550 = Primož Trubar, Abecedarium vnd der klein Catechifmus, Schwäbisch Hall, 1550.

TC $\mathbf{1 5 5 5}$ = Primož Trubar, CATEHISMVS, Tübingen, 1555.

TE 1555 = Primož Trubar, TA EVANGELI SVETIGA MATEVSHA, Tübingen, 1555.

TT 1557 = Primož Trubar, TA PERVI DEIL TIGA NOVIGA TESTAMENTA, Tübingen, 1557.

TR 1558 = Primož Trubar, EN REGISHTER, Tübingen, 1558.

TC 1575 = Primož Trubar, TA CELI CATECHISMVS, Tübingen, 1575.

TT 1581-82 = Primož Trubar, TA CELI NOVI TESTAMENT, Tübingen, 1581-82.

TPo 1595 = Primož Trubar, HISHNA POSTILLA, Tübingen, 1595.

\section{LITERATURA}

Ahačič 2007 = Kozma Ahačič, Zgodovina misli o jeziku in književnosti na Slovenskem: protestantizem, Ljubljana: Založba ZRC, ZRC SAZU, 2007 (Linguistica et philologica 18).

Ahačič 2008 = Kozma Ahačič, Trubarjev prvi Abecednik, v: Primož Trubar, Abecednik (1550), Prevod v sodobni jezik, ur. Kozma Ahačič, Slovenj Gradec: Združenje Trubarjev forum, 2008 (Zbirka Trubar v sodobnem jeziku, zvezek 1), 29-46.

Ahačič 2008-2009 = Kozma Ahačič, Skladnja in retorični modeli v slovenskem knjižnem jeziku 16. stoletja, Slavistična revija 56.4-57.1 (2008-2009) = Trubarjeva številka, ur. Majda Merše, 93-104.

Ahačič 2009 = Kozma Ahačič, Prva slovenska knjiga, v: Primož Trubar, Katekizem (1550) v sodobni knjižni slovenščini, ur. Kozma Ahačič, Slovenj Gradec: Združenje Trubarjev forum, 2009 (Zbirka Trubar v sodobnem jeziku, zvezek 2), 239-260.

Giesemann 2018 = Gerhard Giesemann, Teologija reformatorja Primoža Trubarja, Ljubljana: Založba ZRC, ZRC SAZU, 2018 (Apes academicae 2).

Jelovšek 2016 = Alenka Jelovšek, »My sva téh svetnikov otroci«: dvojina osebnih zaimkov v slovenskem knjižnem jeziku 16. stoletja, Slavistična revija 64.2 (2016), 95-112.

Keber 1986 = Janez Keber, Vzročni vezniki v Trubarjevih delih, v: Družbena in kulturna podoba slovenske reformacije, ur. Darko Dolinar, Ljubljana: Slovenska akademija znanosti in umetnosti, 1986, 111-116.

Legan Ravnikar 2008 = Andreja Legan Ravnikar, Slovenska krščanska terminologija od Brižinskih spomenikov do srede 19. stoletja, Ljubljana: Založba ZRC, ZRC SAZU, 2008 (Lingua Slovenica 4).

Merše 1995 = Majda Merše, Vid in vrstnost glagola v slovenskem knjižnem jeziku 16. stoletja, Ljubljana: Slovenska akademija znanosti in umetnosti, 1995 (Razred za filološke in literarne vede, Dela 44). 
Merše 2009 = Majda Merše, Slovenski knjižni jezik 16. stoletja: razprave o oblikoslovju, besedotvorju, glasoslovju in pravopisu, Ljubljana: Založba ZRC, ZRC SAZU, 2009 (Linguistica et philologica 23).

Merše 2011 = Majda Merše, Trubarjevo prevajanje opomb v Hišni postili, v: Globinska moč besede: red. prof. dr. Martini Orožen ob 80-letnici, ur. Marko Jesenšek, Bielsko-Biała idr.: Mednarodna založba Oddelka za slovanske jezike in književnosti, Filozofska fakulteta, 2011 (Mednarodna knjižna zbirka Zora 80), 106-125.

Merše 2013 = Majda Merše, Slovenski knjižni jezik 16. stoletja: razprave o jezikovnem sistemu, besedju in prevodni problematiki, Ljubljana: Založba ZRC, ZRC SAZU, 2013 (Linguistica et philologica 29).

Merše 2017 = Majda Merše, Raba glagola biti sem v slovenskem knjižnem jeziku 16. stoletja. Jezikoslovni zapiski: ob jubileju Ljubov Viktorovne Kurkine 23.2 (2017), 211-227.

Müller 2008-2009 = Jakob Müller, Temelji slovenskega knjižnega jezika 16. stoletja, Slavistična revija 56.4-57.1 (2008-2009) = Trubarjeva številka, ur. Majda Merše, 165-187.

Neweklowsky 1989 = Gerhard Neweklowsky, Raba podrednih veznikov v Trubarjevem Pismu Rimljanom, Slavistična revija 37.1-3 (1989), 109-119.

Neweklowsky 1995 = Gerhard Neweklowsky, Die Entwicklung der slowenischen Schriftsprache in den ersten zehn Jahren 1550-1560. (Zum zweiten Teil des Neuen Testaments), v: Primus Truber und seine Zeit, München: Verlag Otto Sagner, 1995 (Sagners slavistische Sammlung 24), $309-321$.

Novak 1983/84 = France Novak, Stavčna tipologija v Dalmatinovi Gmajn predguvori čez vso sveto Biblio, Jezik in slovstvo 29.6 (1983/84), 183-187.

Orel 2019 = Irena Orel, Skladenjske razlike v katekizmih slovenskih in hrvaških reformatorjev (Trubar 1550, Konzul 1564; Krelj 1566, Vlačić 1566), Slavia Centralis 12.1 (2019), 182-202.

Orožen 1996 = Martina Orožen, Poglavja iz zgodovine slovenskega knjižnega jezika (od Brižinskih spomenikov do Kopitarja), Ljubljana: Filozofska fakulteta, 1996.

Orožen 2008-2009 = Martina Orožen, Trubarjeva ubeseditev evangelijskih povzetkov v novozaveznih besedilih, Slavistična revija 56.4-57.1 (2008-2009) = Trubarjeva številka, ur. Majda Merše, 319-337.

Pogačnik 1968 = Jože Pogačnik, Zgodovina slovenskega slovstva I, Maribor: Založba Obzorja, 1968.

Pogorelec 1968 = Breda Pogorelec, Razvoj prostega stavka v slovenskem knjižnem jeziku (Vloga dativa v stavku), Jezik in slovstvo 8.5 (1968), 145-150.

Pogorelec 1972 = Breda Pogorelec, Trubarjev stavek, v: Seminar slovenskega jezika, literature in kulture: zbornik predavanj 8, ur. Breda Pogorelec s sodelovanjem Alenke Logar-Pleško, Ljubljana: Univerza v Ljubljani, Filozofska fakulteta, Oddelek za slovanske jezike in književnosti, 1972, 305-321.

Pogorelec 1984 = Breda Pogorelec, Skladnja pri Dalmatinu in Bohoriču, v: XX. Seminar slovenskega jezika, literature in kulture, ur. Jože Koruza, Ljubljana: Univerza Edvarda Kardelja, Filozofska fakulteta, 1984, 223-248.

Pogorelec 1986 = Breda Pogorelec, Dalmatinovo besedilo med skladnjo in retorično figuro in Bohoričeva gramatična norma, v: 16. stoletje v slovenskem jeziku, književnosti in kulturi, ur. Breda Pogorelec - Jože Koruza, Ljubljana: Filozofska fakulteta, 1986 (Obdobja 6), 473-497.

Pogorelec 2011 = Breda Pogorelec, Zgodovina slovenskega knjižnega jezika: jezikoslovni spisi 1, ur. Kozma Ahačič, Ljubljana: Založba ZRC, ZRC SAZU - Znanstvena založba Filozofske fakultete, 2011 (Lingua Slovenica, Fontes 1).

Rajhman 1977 = Jože Rajhman, Prva slovenska knjiga v luči teoloških, literarno-zgodovinskih, jezikovnih in zgodovinskih raziskav, Ljubljana: Partizanska knjiga, 1977.

Sajovic 1986 = Tomaž Sajovic, Retoričnost in besedilnost Trubarjeve pridige, v: 16. stoletje v slovenskem jeziku, književnosti in kulturi, ur. Breda Pogorelec - Jože Koruza, Ljubljana: Filozofska fakulteta, 1986 (Obdobja 6), 499-513.

Seitz 1995 = Elisabeth Seitz, Govorniško sredstvo ali pomoč pri prevajanju?: dvojično vezniško priredje v izbranih besedilih Primoža Trubarja, Martina Lutra in njunih sodobnikov, Slavistična revija 43.4 (1995), 469-489. 
Toporišič 1982 = Jože Toporišič, Nova slovenska skladnja, Ljubljana: Državna založba Slovenije, 1982.

Toporišič 1992 = Jože Toporišič, Enciklopedija slovenskega jezika, Ljubljana: Cankarjeva založba, 1992.

Toporišič $\mathbf{2 0 0 0}$ = Jože Toporišič, Slovenska slovnica, Maribor: Založba Obzorja, 42000.

Vidovič Muha 2013 = Ada Vidovič Muha, Slovensko leksikalno pomenoslovje, Ljubljana: Univerza v Ljubljani, Filozofska fakulteta, 2013 (Razprave FF).

\section{SUMMARY}

\section{Simple Sentences in Primož Trubar's Catechismus and Abecedarium (1550)}

Despite the prevalence of complex sentences in Trubar's Catechismus and Abecedarium (1550), the first two books in Slovenian include a fair number of simple sentences. These sentences vary in their form, function, and semantics, which is a consequence of the fact that they are included in typologically specific but similar texts: in Catechismus as an essential devotional manual, and in Abecedarium as an essential literacy manual. Both works are thought to have been independently compiled, with only partial reliance on translation of source texts. In Trubar's Catechismus and Abecedarium, simple sentences that include all sentence elements are rare. More common are sentences that omit individual elements. This is to some extent the result of the fact that simple sentences are firmly embedded in the context. In addition to two-part sentences (with a subject and a predicate), one-part sentences are particularly noticeable in both works. The most prominent among them - with regard to their frequency and function in the text - are non-verbal sentences; for example, Ozha 'Father' (TA 1550: AVb) and VY muy lubefniui bratye inu feftre/ 'You my beloved brothers and sisters' (TC 1550: 67). The analysis of syntactic mood showed the prevalence of narrative sentences. Within the text, these sentences fulfill various roles: in addition to plain indicative sentences, there are also sentences that explain or define, entitle, or address, used in the form of opening or closing formulas; for example, VSEM Slouenzom/Gnado/ Myr/ Mylhoft inu prauu Spofnane bofhye/ fkufi Iefufa Chriftufa proffim 'I ask for grace, peace, mercy, and true divine insight for all Slovenians through Jesus Christ' (TC 1550: AIIIa), or in the form of a verse. Many of them are stylistically particularly effective because they include stylistic or rhetorical devices (e.g., double or triple formulas, chiasmus, and idiosyncratic word order, such as frequent transposition of the attribute). The increased expressiveness of some sentences is also due to the choice of attributes, terminology, inclusion of diminutives, and repetition of analogous expressions. Narrative simple sentences are followed by interrogative, imperative, and optative sentences. The latter two groups are characterized by a broad spectrum of emotional and modal modification. Interrogative simple sentences also include seemingly interrogative sentences, whereas imperative sentences comprise commands and prohibitions. Simple sentences in Trubar's first two works show other features of Trubar's standard language; for example, the use of the article, calqued prepositional phrases, or inconsistently expressed agreement. 